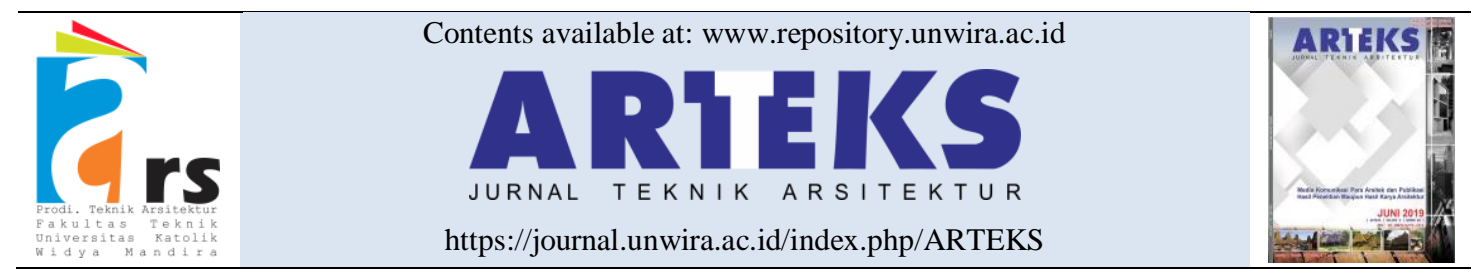

Research paper

doi: http://doi.org/10.30822/arteks.v4i1.77

\title{
Pendekatan antropologi sebagai penyeimbang model perhitungan jejak ekologis di Desa Wisata
}

\author{
Anna Pudianti* (i), Vincentia Reni Vitasurya \\ Program Studi Arsitektur, Fakultas Teknik, Universitas Atma Jaya Yogyakarta \\ Jl. Babarsari, No. 44, Yogyakarta - 55281, Indonesia
}

\begin{tabular}{|c|c|}
\hline ARTICLE INFO & ABSTRACT \\
\hline $\begin{array}{l}\text { Article history: } \\
\text { Received April 20, } 2019 \\
\text { Received in revised form May 15, } 2019 \\
\text { Accepted September 13, } 2019 \\
\text { Available online December 16, } 2019\end{array}$ & $\begin{array}{l}\text { Anthropology approach as a balancer of ecological footprint } \\
\text { calculation models in Tourism Village } \\
\text { Tourism is currently experiencing a shift from mass tourism to } \\
\text { special interest tourism focusing on nature and culture. In the } \\
\text { context of preservation, rural tourism experiences a sharp pros and }\end{array}$ \\
\hline $\begin{array}{l}\text { Corresponding author: Anna Pudianti } \\
\text { Program Studi Arsitektur, Fakultas Teknik, } \\
\text { Universitas Atma Jaya Yogyakarta, } \\
\text { Yogyakarta, Indonesia } \\
\text { Email: pudiantianna2014@ gmail.com } \\
\text { ORCID: https://orcid.org/0000-0002-6352- } \\
\text { 5926 }\end{array}$ & $\begin{array}{l}\text { uses one of the environmental conservation evaluation instruments } \\
\text { with an ecological footprint calculation model that analyzes } \\
\text { quantitatively the aspects of transportation, water use, clothing use, } \\
\text { recreation, food, garbage and shelter. Given the limitations of the } \\
\text { ecological trace calculator model to be applied in tourism villages, } \\
\text { the implementation of the model needs to be modified using the } \\
\text { anthropological approach. The research method used is action } \\
\text { research participation by measuring the impact of tourism activities } \\
\text { in rural areas using simple indicators of ecological footprint } \\
\text { calculations and equipped with in-depth interviews to explore } \\
\text { aspects of collective behavior as the focus of the anthropological } \\
\text { approach studied. Case studies include three villages in the } \\
\text { Yogyakarta region, namely Pentingsari in Sleman regency, Lopati } \\
\text { in Bantul and Kalibiru districts in Kulonprogo district. The results } \\
\text { obtained are recommendations for anthropological approaches to } \\
\text { evaluate the ecological footprint results so that they are more } \\
\text { appropriate if they are used as an environmental conservation } \\
\text { action plan in a tourist village with the emphasis on forming } \\
\text { awareness of living with nature. }\end{array}$ \\
\hline
\end{tabular}

\section{Pendahuluan}

Pariwisata perdesaan merupakan model pariwisata baru, sering juga dikenal dengan pariwisata minat khusus (special interest tourism). Ekowisata memang merupakan pengembangan pariwisata baru-baru ini banyak dikembangkan di Indonesia, walaupun secara internasional sejak Oktober 1999 sebenarnya telah dikeluarkan "Global Code of Ethics for Tourism" (Frangialli 1999) sebagai dorongan kepada negara-negara di dunia untuk mengembangkan pariwisata berkelanjutan. Yogyakarta yang menyandang kota pariwisata juga tidak luput dari pengaruh "trend" wisata berbasis ekologi. Bentuk aktivitas pariwisata berbasis ekowisata dan atau budaya mulai bermunculan di Daerah Istimewa Yogyakarta khususnya dalam bentuk desa wisata. Menurut Fandeli, (2002) desa wisata dijabarkan sebagai suatu wilayah pedesaan yang menawarkan keseluruhan suasana yang mencerminkan keaslian desa, baik dari segi kehidupan sosial budaya, adat istiadat, aktifitas keseharian, 
arsitektur bangunan, dan struktur tata ruang desa, serta potensi yang mampu dikembangkan sebagai daya tarik wisata, misalnya: atraksi, makanan dan minuman, cinderamata, penginapan, dan kebutuhan wisata lainnya (Fandeli 2002).

Secara teoritis "trend" basis ekologi dalam pengembangan wisata merupakan fenomena yang positif jika dilihat sebagai suatu ciri lingkungan yang berkelanjutan. Pariwisata berkelanjutan di perdesaan memiliki makna mengembangkan kawasan pedesaan menjadi desa wisata yang berbasis pada kelestarian lingkungan alamiah yang mengandalkan gaya hidup agraris sebagai salah satu atraksi wisatanya, namun memiliki nilai ekonomis yang lebih besar dari sebelumnya (Purbadi dan Lake 2019). Seiring dengan peningkatan ekonomi masyarakat, maka akan diikuti pula dengan bentuk modernisasi yang beragam yang lambat laun mungkin mengancam upaya pelestarian itu sendiri.

Dampak lingkungan sebagai akibat dari perkembangan wisata perlu disadari sedini mungkin agar wisata perdesaan tidak berkembang menjadi kegiatan wisata yang tidak terkendali. United Nation Environment Programme (2015) menjabarkan, dampak utama pariwisata terhadap lingkungan terbagi menjadi tiga dampak besar, yaitu berkurangnya sumber daya alam, bertambahnya polusi, dan dampak terhadap ekosistem.

Dampak sumber daya alam terkait langsung dengan kekayaan alam dasar kehidupan yang sangat mungkin berkurang jika digunakan untuk pengembangan. Contohnya pembangunan lahan untuk dijadikan rumah berakibat berkurangnya luas lahan untuk menyerap air. Dalam konteks wisata, setiap lahan terbangun untuk fasilitas wisata membawa konsekuensi lahan terbangun meningkat. Poin kedua, bertambahnya polusi akibat perjalanan menuju dan dari lokasi wisata. Perjalanan wisatawan ke daerah destinasi wisata membutuhkan waktu dan energi yang cukup banyak. Untuk sampai ke suatu daerah wisata, wisatawan memakai kendaraan dengan bahan bakar yang berkontribusi pada perubahan iklim melalui emisi CO2. Poin ketiga yaitu dampak terhadap ekosistem telah terlihat dari contoh poin pertama dan kedua yang merupakan rantai sebab akibat dari beberapa peristiwa akibat aktifitas wisata. Contohnya wisata membutuhkan fasilitas, membutuhkan transportasi sehingga juga membutuhkan pengembangan budidaya pembangunan lahan, namun sekaligus mengurangi sumber daya dan bahkan meninggalkan polusi. Ekosistem berubah sebagai akibat berubahnya aktifitas, yang dalam hal ini adalah aktifitas wisata dengan segala aktifitas ikutannya.

Perilaku hidup wisatawan sehari-hari selama berwisata juga memiliki dampak cukup besar terhadap daerah wisata apabila melebihi daya dukungnya, sehingga diperlukan suatu metoda yang dipergunakan untuk mengukur dampak pariwisata berdasarkan perilaku hidup sehari-hari wisatawan dan warga penyelenggara wisata. Metoda yang mungkin digunakan adalah metoda jejak ekologi. Jejak ekologis adalah suatu alat bantu untuk mengukur penggunaan sumberdaya dan kemampuan bumi dihubungkan dengan tingkah laku dan gaya hidup manusia (Wackernagel et al. 1997, Wackernagel dan Monfreda 2004). Jejak ekologis dinyatakan dalam satuan hektar, dan digunakan sebagai ukuran prestasi kita dalam mendukung keberlanjutan dari bumi. Alat ukur ini berguna untuk mengetahui apakah kegiatan konsumsi yang dilakukan manusia masih berada dalam batas daya dukung lingkungan ataukah sudah melewati batas.

Tiga (3) studi kasus desa wisata di Yogyakarta digunakan pada riset, sebagai dasar tulisan ini, dengan tujuan untuk menilai jejak ekologis di desa wisata. Pemilihan tiga contoh desa wisata mewakili karakteristik desa wisata yang dalam klasifikasi berkembang dengan tiga karakteristik yang berbeda yaitu wisata alam pedesaan, wisata bentang alam, dan wisata industri kerajinan dan makanan kecil. Hasil yang didapat dari pengukuran awal menunjukkan penjabaran aspek yang agak berbeda dengan kenyataan, karena alat ukur jejak wisata kurang dapat menggambarkan aspek budaya, perilaku, dan keanekaragaman. Permasalahan gap antara alat ukur jejak ekologi dengan studi empiris memunculkan ide tulisan yang bertujuan untuk melengkapi alat ukur jejak wisata dengan pendekatan antropologi sebagai upaya mengakomodasi berbagai aspek budaya, perilaku dan keanekaragaman kehidupan manusia.

Studi mengenai jejak ekologi sebenarnya sudah banyak diteliti dan dikembangkan dengan berbagai versi. Instrumen pengukuran jejak ekologis telah menarik peneliti dalam dekade terakhir. Perkembangan teknologi informasi juga mendorong pengembangan model penghitungan jejak ekologi dengan basis program kalkulator mini berbasis online dengan substansi pada pemahaman jejak ekologi (Südaş dan Özeltürkay 2015). Aspek ekonomi pada jejak ekologi juga 
menarik para peneliti (Patterson, Niccolucci, dan Bastianoni 2007), dan (Sthel, Tostes, dan Tavares 2013). Turunan dari aspek ekologi secara spesifik untuk aktivitas wisata bahkan juga sudah dilakukan beberapa peneliti, seperti kaitan antara nilai jejak ekologis dengan kegiatan wisata di Italia (Patterson, Niccolucci, dan Bastianoni 2007), pemanfaatan wisata yang telah melampaui batas dirasakan di Venice (Bagliani et al. 2004), sedangkan Wang merekomendasi penghitungan jejak ekologi wisata harus diikuti oleh jejak carbon wisata dan jejak penggunaan air (Wang et al. 2017). Penelitian jejak ekologi lebih banyak mengambil studi kasus di kawasan perkotaan, sedangkan di kawasan perdesaan masih belum banyak dilakukan.

Pudianti, Vitasurya, Purwaningsih, \& Herawati, (2014) menegaskan diperlukannya penelitian lanjutan yang menggambarkan aspek masyarakat sebagai pemeran utama desa wisata untuk melengkapi model perhitungan jejak ekologi yang digunakan untuk melihat efektifitas pelestarian lingkungan dari keberadaan desa wisata. Pada kelanjutan penelitian V.R Vitasurya, Pudianti, Purwaningsih, \& Herawati, (2015) menemukan kearifan lokal dalam pengelolaan lingkungan di desa wisata (Reni Vitasurya et al. 2014, V. R Vitasurya et al. 2015). Aspek masyarakat dengan kearifan lokalnya memang tidak terwakili dalam aspek yang dibahas dalam jejak ekologi (versi modifikasi dari model Wackernagel \& Rees., (1998)). Reid \& Schwab, (2006) juga melihat adanya hambatan budaya dalam pengembangan wisata di Jordania dari aspek kemasyarakatan dengan adanya hiraki dalam kepemimpinan lokal, yang membutuhkan intervensi kepemimpinan dari pemerintah untuk menjembatani perbedaan budaya antar pemimpin lokal (Reid 2006). Demikian pula Hwang, Stewart, \& Ko, (2012) menekankan pentingnya mempertimbangkan gerakan kolektif pada masyarakat perdesaan yang mempengaruhi pengembangan desa wisata (Hwang, Stewart, dan Ko 2012).

Dari berbagai penelitian yang telah dilakukan, disimpulkan perlunya memasukkan pendekatan antropologi pada model perhitungan jejak ekologi khususnya untuk kasus wisata di perdesaan. Peneliti terdahulu telah menunjukkan bahwa aspek tingkah laku, tradisi dan kearifan lokal di perdesaan sangat berpotensi mempengaruhi berbagai aspek kehidupan di desa termasuk berkembangnya desa wisata. Oleh karena itu tulisan ini bertujuan untuk mendiskusikan kekurangan yang ada pada model perhitungan jejak ekologi jika tidak menggunakan pendekatan antropologi, khususnya jika diterapkan pada kasus wisata perdesaan. Pendekatan antropologi memberi gambaran yang lebih kaya, jelas dan nyata dari hasil perhitungan jejak ekologi pada kasus desa wisata.

\section{Metode penelitian}

Penelitian ini menggunakan metode studi kasus dengan menggunakan tiga objek desa wisata yaitu desa Pentingsari di Sleman, Desa Kalibiru di Kulonprogo dan Desa Lopati di Bantul. Kriteria pemilihan desa wisata berdasarkan keunikan dalam pengembangan pariwisata perdesaan. Desa Pentingsari memiliki keunikan suasana perdesaan dengan mempertahankan bentang alam perdesaan. Desa Kalibiru memiliki keunikan objek wisata alam pegunungan dengan pemandangan alam yang unik di lereng perbukitan yang merupakan hasil penghijauan hutan rakyat sebagai partisipasi masyarakat untuk menjaga pasokan air bersih. Desa Lopati memiliki keunikan etos kerja warga yang berprofesi sebagai pengrajin terutama makanan tradisional yang diolah secara tradisional.

Pemilihan kasus desa wisata mengutamakan keunikan khas pedesaan sebagai potensi daya tarik wisatanya. Keunikan yang khas setiap desa menarik wisatawan untuk berkunjung. Daya tarik wisata di Desa Pentingsari mengutamakan keunikan kehidupan pedesaan. (Lihat Gambar 1.a) Hal ini juga ditunjang dengan bentang alam pegunungan yang asri serta jaraknya yang terjangkau dari kotaYogyakarta. Desa ini juga memiliki sejumlah prestasi, diantaranya sebagai juara I lomba antar desa wisata tingkat Nasional untuk kategori "Alam yang Unik dan Pelestarian Budaya" pada tahun 2009, dan juga penghargaan dari PBB untuk kategori "Pelestarian Alam dan Budaya" pada tahun 2011.

Desa Kalibiru memiliki keunikan tersendiri yang ditunjang oleh keberadaan objek wisata alam Kalibiru berupa wisata pegunungan dengan pemandangan indah yang dikemas secara unik ke arah Waduk Sermo. (Lihat gambar 1.b) Lokasi wisata alam yang menyatu dengan hutan lindung sebagai bagian dari konservasi lahan, mengakibatkan desa ini menarik bagi wisatawan pencinta alam. Desa ini juga memiliki sejumlah prestasi, diantaranya meraih juara 1 desa wisata 
sepropinsi Daerah Istimewah Yogyakarta (DIY) dan juara 4 desa wisata nasional 2014.

Keunikan khas yang dimiliki oleh desa wisata Lopati yaitu desa ini dikenal karena memiliki ragam kerajinan yang masih diolah secara tradisional oleh warganya, terutama kerajinan (lihat gambar 1.c.), batik bambu, kronjot/krondho dan meubeler dan kuliner tradisional seperti mie lethek, bakpia, tahu, tempe koro maupun kedelai. Hal ini menjadi daya tarik khusus bagi wisatawan yang tertarik mempelajari kerajinan tradisional.
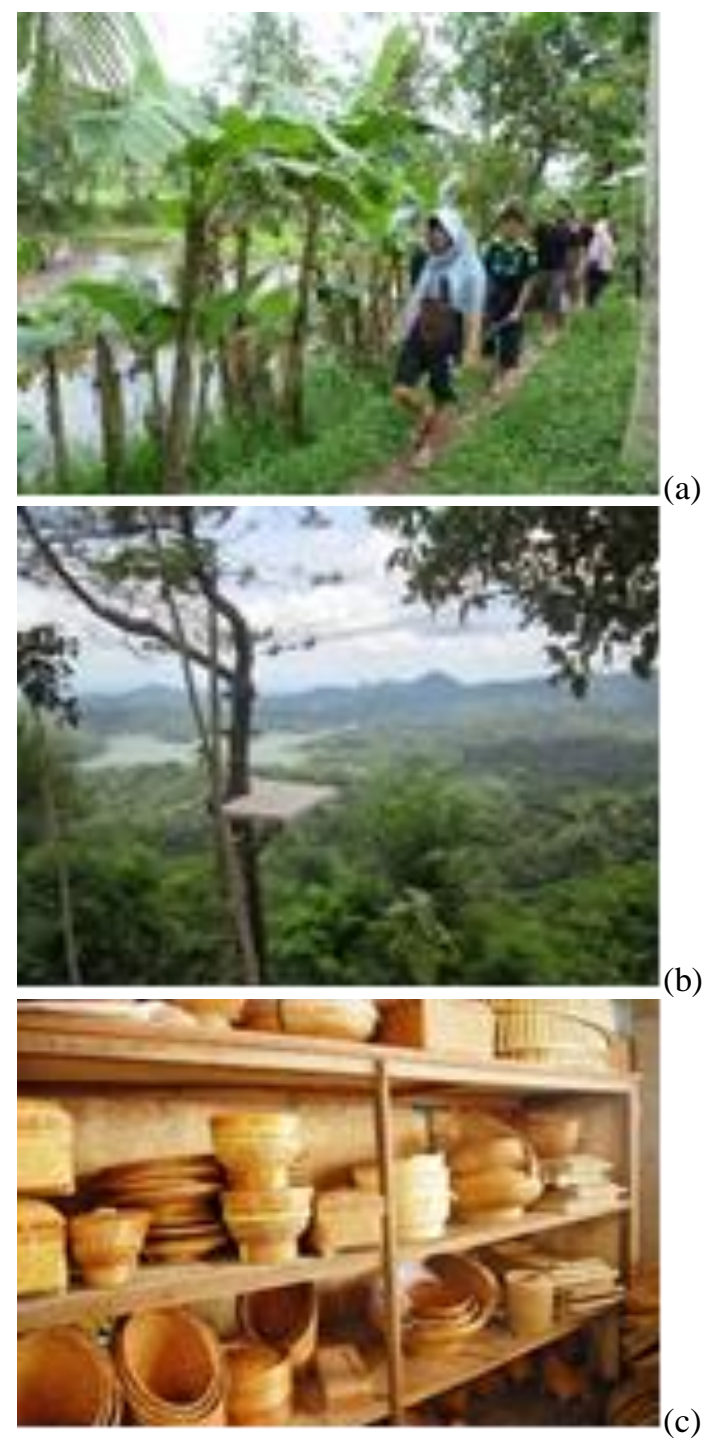

Gambar 1. Atraksi wisata: (a) kehidupan perdesaan di Pentingsari; (b) pemandangan alam di Kalibiru; dan (c) kerajinan bambu di Lopati
Teknik penelitian Partisipatif Riset Aksi ( $\mathrm{PAR}=$ Participation Action Research) digunakan untuk menggali data keseharian masyarakat desa dan wisatawan dalam aktifitas wisata dengan perspektif pelestarian lingkungan. Jenis penelitian ini menekankan pelibatan sasaran sebagai subyek yang aktif, menjadikan pengalaman mereka sebagai bagian integral dalam penelitian, menemukan permasalahannya, dan semuanya diarahkan untuk pemecahan persoalan sasaran dalam konteks pemberdayaan subyek penelitian. Untuk mencapai hal ini, maka kegiatan penelitian dan aksi menjadi satu kesatuan kegiatan yang berjalan berkesinambungan dan saling mengisi untuk menemukan pemecahan masalah atas subyek yang diteliti. Metode partisisipatif riset aksi diidentikkan dengan riset pemberdayaan (Mikkelsen 1995). PAR diperlukan untuk menggali penilaian jejak ekologis baik dari sisi warga desa maupun wisatawan, namun sekaligus memberi kesadaran pada pelaku wisata tentang jejak ekologi yang diciptakan dari kegatan wisata di perdesaan.

Metode penilaian jejak ekologi diambil dari konsep jejak kaki ekologis yang pertama kali diciptakan oleh Wackernagel \& Rees., (1998). Model Warnekel dimodifikasi sesuai dengan aspek pariwisata berdasarkan perilaku hidup manusia dalam jejak ekologis yang memiliki empat kategori konsumsi, yaitu (1) karbon, yang terdiri dari konsumsi energi harian dan mobilitas atau transportasi, (2) rantai makanan, (3) akomodasi atau tempat berteduh, (4) barang dan jasa, yang terdiri dari kebiasaan dalam berekreasi. Aplikasi perhitungan jejak ekologi yang digunakan merupakan modifikasi dari model individual footprint calculator Global Footprint Network, (2018) dengan indikator: transportasi, penggunaan air, pakaian, peralatan, makanan, sampah dan lahan tempat tinggal. (Tabel 1) Model perhitungan disederhanakan agar mudah dipahami dan tidak terlalu kompleks untuk digunakan secara individu oleh para pengelola desa wisata maupun wisatawan. Semakin kecil hasil nilai akhir, maka jejak ekologi semakin baik yang berarti memberi dukungan keberlanjutan bumi lebih tinggi. 
Tabel 1. Instrumen nilai jejak ekologi per aspek

\begin{tabular}{l}
\hline Indikator jejak ekologi \\
\hline A. Transportasi \\
\hline Nilai jejak ekologi berbeda untuk setiap jenis moda \\
transportasi yang digunakan, termasuk pembeda transportasi \\
umum dan massal
\end{tabular}

\section{Poin Keterangan}

(interval 5)

$0-30$

$$
\begin{aligned}
& \text { Jejak ekologi transporatsi masal digunakan } \\
& \text { untuk mencapai lokasi. } \\
& \text { Point harus dikalikan dengan frekuensi } \\
& \text { kegiatan dilakukan }
\end{aligned}
$$

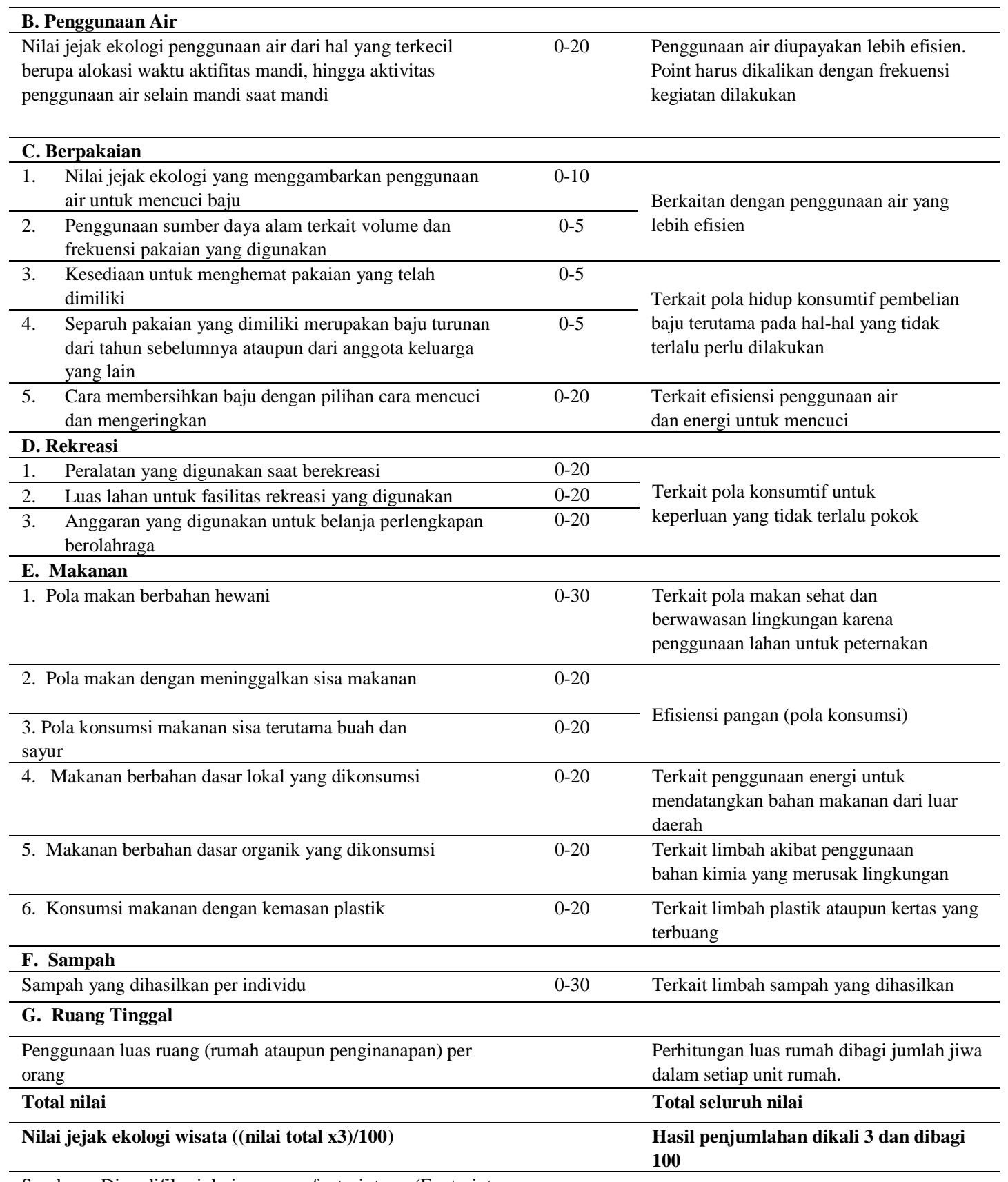

Sumber : Dimodifikasi dari www.myfootprint.org (Footprint 2016) 
Purposive sampling diterapkan untuk memberi gambaran jejak ekologis yang terbesar akibat aktifitas yang dilakukan berdasar kelompok pelaku utama. Kelompok sampel terbagi menjadi dua bagian besar yaitu warga desa wisata yang diwakili pengelola dan wisatawan yang berkunjung ke desa wisata. Kelompok sampel wisatawan dipilih dari kelompok wisatawan inap yang paling banyak berkunjung yaitu kelompok pelajar dan instansi untuk desa wisata Pentingsari, kelompok pelajar untuk desa wisata Kalibiru dan kelompok pelajar dan instansi untuk desa wisata Lopati masing-masing dengan jumlah 30 orang. Bagi pengelola desa wisata dilakukan perbandingan perhitungan antara aktifitas sebelum dan sesudah menjadi desa wisata. Bagi wisatawan perhitungan dilakukan dengan membandingkan aktifitas wisatawan dengan model rekreasi yang pernah dilakukan dan dibandingkan dengan aktifitas rekreasi di desa wisata. Jejak ekologis di Desa Pentingsari dilakukan pada periode puncak kunjungan wisatawan yaitu pada bulan Mei - Juni sesuai dengan kalender akademik pelajar sebagai wisatawan dominan.

\section{Temuan dan pembahasan}

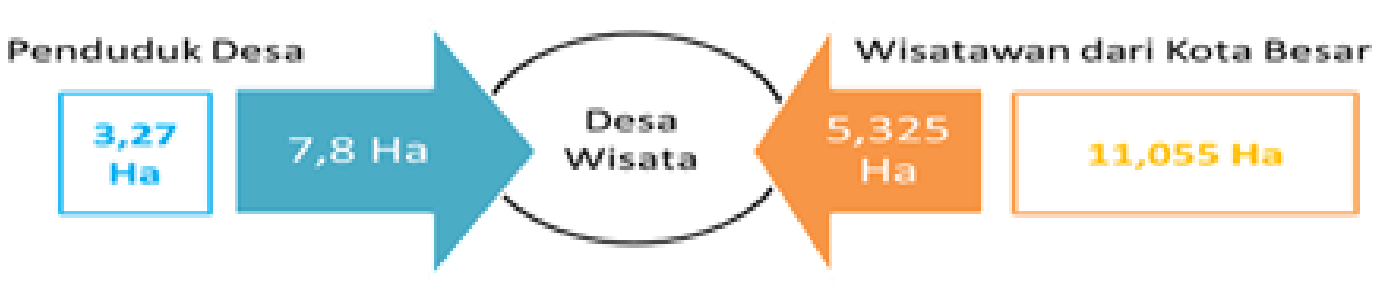

\section{Perbandingan Jejak Ekologis Desa Wisata Alam dengan Homestay}

Gambar 2. Jejak ekologis di Desa Pentingsari

Peningkatan jejak ekologis setelah menjadi desa wisata diakibatkan bertambahnya aktifitas warga untuk memberi pelayanan jasa kepada wisatawan. Tradisi bermukim warga Desa Pentingsari sebelum menjadi desa wisata sebenarnya sangat berorientasi pada kelestarian lingkungan. Contohnya pola makan dengan memanfaatkan tanaman yang sengaja ditanam untuk dikonsumsi, sayuran dan buah yang berada di sekeliling pekarangan merupakan sumber bahan makanan yang sewaktu-waktu dipetik

Pembahasan didahului dengan hasil penilaian jejak ekologis setiap desa studi kasus, kemudian hasil yang diperoleh dibandingkan dengan fakta empiris di lapangan. Fokus pembandingan di lapangan bertujuan untuk melihat perbedaan hasil jika diperdalam dengan menggunakan pendekatan antropologi.

\section{Gap nilai jejak ekologi dan argumentasi antropologi}

Berdasarkan hasil, disimpulkan bahwa jejak ekologis desa Pentingsari meningkat dari 3.27 ha menjadi 7.8 ha atau sebesar $243 \%$ (2.4 kali) jika diukur dari sebelum menjadi desa wisata hingga sesudah menjadi desa wisata. Hal ini mengindikasikan bahwa aktivitas wisata membawa dampak meningkatnya pemanfaatan sumber daya alam. Sedangkan dari sisi wisatawan, terlihat bahwa dengan berwisata ke desa wisata, jejak ekologis yang mereka hasilkan menurun dari 11.055 ha menjadi 5. 325 ha atau $48.1 \%$, hal ini mengindikasikan bahwa wisata ke desa menurunkan pemanfaatan sumber daya alam dengan kata lain hal ini berdampak positif bagi jejak ekologi wisatawan. Hasil jejak ekologi dari sisi warga desa dan dari sisi wisatawan menunjukkan angka yang berlawanan, yaitu peningkatan persentase jejak ekologis warga desa dan penurunan pada jejak ekologis wisatawan. Hasil yang diperoleh diilustrasikan pada gambar 2. 
penurunan. Penyebab turunnya jejak ekologi wisatawan disebabkan terutama karena perubahan profil tempat menginap selama berwisata. Jika semula menggunakan fasilitas wisata dengan berbagai kebutuhan konsumtif, sebaliknya di desa wisata gaya berwisata berubah menjadi berorientasi pada pemanfaat sumber daya alam secara lebih efisien. Ruang inap wisatawan merupakan rumah warga yang sudah sejak lama ada dan dengan ruang tidur merupakan ruang tidur anggota keluarga yang beberapa saat tidak digunakan karena pindah bekerja di kota. Fakta ini membuat jejak ekologi wisatawan turun akibat efisiensi pemanfaatan ruang di rumah (homestay).

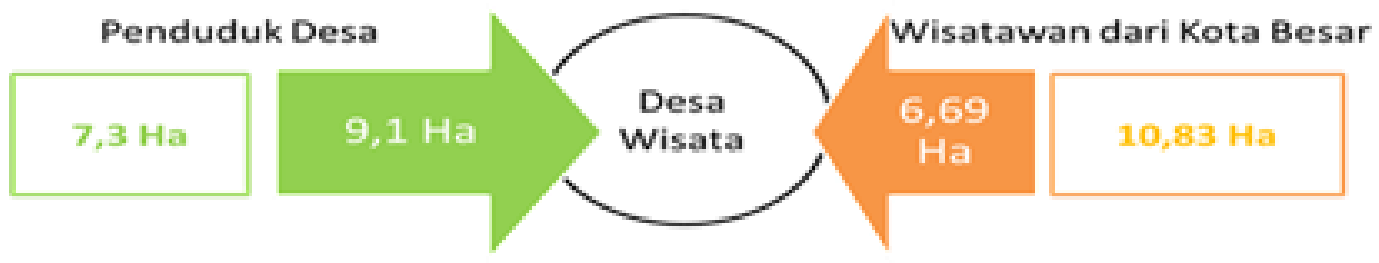

Perbandingan Jejak Ekologis Desa Wisata Hutan Alam dengan Pondok Wisata

Gambar 3. Jejak ekologis di Desa Kalibiru

Berdasarkan hasil perhitungan, disimpulkan bahwa jejak ekologis Desa Kalibiru meningkat dari 7.3 ha menjadi 9.1 ha atau sebesar $24.7 \%$ jika diukur dari sebelum menjadi desa wisata hingga sesudah menjadi desa wisata. Hal ini mengindikasikan bahwa aktivitas wisata membawa dampak meningkatnya pemanfaatan sumber daya alam. Sedangkan dari sisi wisatawan, terlihat bahwa dengan berwisata ke desa wisata, jejak ekologis yang dihasilkan menurun dari 10.83 ha menjadi 6.69 ha atau $38.2 \%$, hal ini mengindikasikan bahwa wisata ke objek wisata alam menurunkan pemanfaatan sumber daya alam dengan kata lain hal ini berdampak positif bagi wisatawan. Dari angka peningkatan maupun penurunan jejak ekologis terlihat bahwa persentase peningkatan jejak ekologis warga desa dan penurunan jejak ekologis wisatawan yang berkunjung hampir seimbang.

Kecenderungan peningkatan dan penurunan jejak ekologi di Desa Kalibiru tampak sama dengan yang terjadi di Pentingsari, akan tetapi sebenarnya ada perbedaan yang cukup besar secara substansi. Nilai awal sebelum menjadi desa wisata di Pentingsari cukup rendah yaitu 3.27, sedang di Kalibiru 7.3. Perbedaan yang mendasar dari kasus kedua desa adalah pada Desa Pentingsari tradisi hidup dengan menekankan pada kelestarian alam telah menjadi bagian dari aktivitas keseharian warga. Berbeda dengan yang terjadi di Kalibiru (Vincentia Reni dan Anna 2016) pada awalnya tradisi hidup dengan alam belum menjadi tradisi kehidupan warga desa.
Hutan yang menjadi sumber kekayaan alam di Kalibiru dalam kondisi rusak antara 1997-2000. Dan baru dikelola kembali secara baik sejak tahun 2000. Setelah delapan tahun, terbentuk Kelompok Tani Hutan Kemasyarakatn mandiri (KTHKm) yang berorientasi pada kelestarian alam. Dan hutam dikelola menjadi atraksi wisata alam sejak tahun 2008.

Berbeda dengan Pentingsari yang mengembangkan homestay dari rumah tempat tinggal mereka sendiri, di Kalibiru pondok wisata dibangun di lingkungan hutan untuk tempat inap wisatawan. Hal inilah yang menyebabkan angka jejak ekologis di Kalibiru mencapai 9.1, sedangkan di Pentingsari hanya mencapai 7.8. Perubahan gaya hidup di Pentingsari terasa sekali lonjakannya setelah menjadi desa wisata walaupun sebenarnya dengan keberadaan desa wisata justru atraksi kedekatan dengan alam masih menjadi andalan orientasi wisata Pentingsari. Fenomena inilah yang menyebabkan kebutuhan pendekatan antropologis perlu menjadi mitra penghitungan jejak ekologis agar dapat melihat secara lebih dalam tradisi dan kearifan lokal yang berkembang di dalam masyarakat.

Kasus di Desa Lopati dengan potensi wisata industry kuliner dan kerajinan tradisional sangat berbeda dengan kedua desa yang lain. Pelaku wisata pada awalnya sebagian besar adalah kelompok ibu - ibu PKK (Pembinaan Kesejahteraan Keluarga) sebagai wisatawan dominan (Vincentia Reni dan Anna 2016). Hasil yang diperoleh diilustrasikan gambar 4 . 


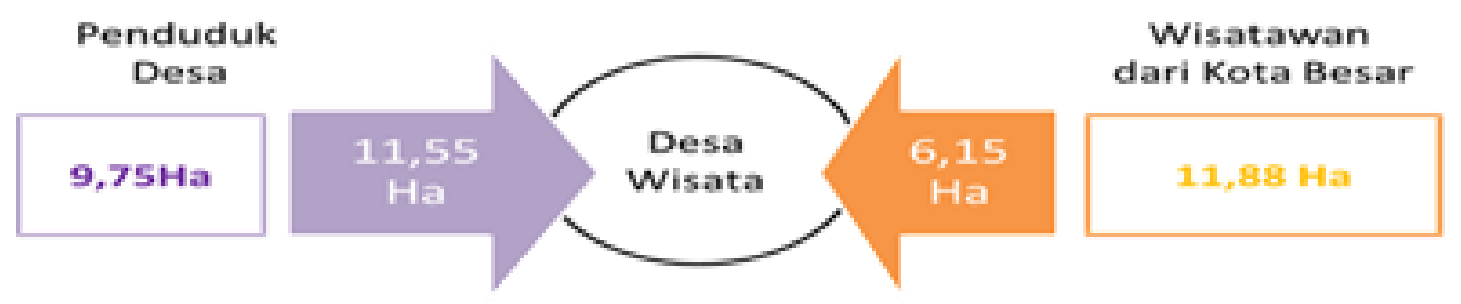

\section{Perbandingan Jejak Ekologis Desa Wisata Industri Kuliner}

Gambar 4. Jejak ekologis di Desa Lopati

Berdasarkan hasil, disimpulkan bahwa jejak ekologis Desa Lopati meningkat dari 9.75 ha menjadi 11.55 ha atau sebesar $18.5 \%$ jika diukur dari sebelum menjadi desa wisata hingga sesudah menjadi desa wisata. Hal ini mengindikasikan bahwa aktivitas wisata membawa dampak meningkatnya pemanfaatan sumber daya alam. Sedangkan dari sisi wisatawan, terlihat bahwa dengan berwisata ke desa wisata, jejak ekologis yang mereka hasilkan menurun dari 11.88 ha menjadi 6.15 ha atau $48.2 \%$, hal ini mengindikasikan bahwa wisata ke desa wisata menurunkan pemanfaatan sumber daya alam dengan kata lain hal ini berdampak positif bagi wisatawan. Hasil jejak ekologis secara umum juga tidak jauh berbeda dengan kasus Pentingsari dan Kalibiru, namun berbeda dalam detil substansi secara empiris.

Dengan menggunakan pendekatan antropologi terlihat perbedaan utama terletak pada sumber mata pencaharian utama di Desa Lopati. Lopati merupakan desa yang tidak memiliki sawah, kehidupan sehari-hari lebih banyak ditunjang oleh produksi aneka makanan tradisional seperti bakpia, tempe, mi dari singkong (mie lethek) dan juga produksi kerajinan keranjang (kronjot) sepeda atau sepeda motor dan kerajinan bambu. Aneka barang dan makanan produksi Desa Lopati sejak awal telah meninggalkan jejak ekologi yang cukup tinggi. Aspek tertinggi terletak pada aspek transportasi, sampah dan ruang tinggal.

Tingginya jejak ekologi pada aspek transportasi, sampah dan ruang tinggal merupakan konsekuensi dari aktivitas industri rumahan. Dari wawancara disimpulkan bahwa peningkatan pada transportasi disebabkan perjalanan untuk pengadaan bahan baku dan distribusi atau pengiriman barang hasil produksi. Produksi barang dan makanan selain meninggalkan polusi udara, juga polusi air limbah dari hasil pencucian bahan baku serta sisa air rebusan bahan baku ditambah pula sampah padat beupa sisa bahan baku. Untuk aspek ruang tinngal, peningkatan jejak ekologi disebabkan ruang yang dibangun atau ruang yang telah ada dimanfaatkan sebagai ruang produksi, namun jumlah jiwa sebagai pembagi nilai jejak ekologi tidak bertambah.

Setelah menjadi desa wisata peningkatan jejak ekologi bertambah pada aspek transportasi wisatawan, aspek sampah dari kemasan konsumsi wisatawan dan aspek penggunaan air untuk pelayanana wisatawan dan pencucian peralatan.

\section{Karakter masyarakat desa wisata berdasarkan hasil jejak ekologis}

Berdasar pembahasan awal pendekatan antropologi pada sub bab gap nilai ekologis dan argumentasi antropologis di atas, terlihat kebutuhan untuk menganalisis secara mendalam latar belakang pola kehidupan masyarakat perdesaan di ketiga desa, agar mendapatkan gambaran secara menyeluruh keasadaran warga masyarakat pada kelestarian alam. Pencermatan secara holistik harus dilakukan dengan mengkaitkan warga masyarakat secara berkelompok dan tempat tinggal (territorial) (Baal 1988).

Desa Pentingsari terletak di lereng Merapi dengan akses yang sangat terbatas. Tanah yang subur dengan lokasi yang termasuk rawan bencana gunung meletus menyebabkan masyarakat yang bermukim sejak sekitar 1800-an sangat dekat dengan alam. Penghargaan terhadap alam mendapat tempat yang tinggi karena penghidupan warga desa mengandalkan hasil bumi yang berasal dari pertanian, dan perkebunan. Hingga saat ini masyarakat masih memiliki jiwa kedekatan dengan alam. Salah satu contohnya seorang tokoh yang telah lanjut usia pada tahun 2017 mendapat penghargaan kalpataru karena jasanya melaukan penghijauan di sepanjang lembah sungai yang sempat rusak 
terkena bencana letusan Merapi pada tahun 2010. Upaya tokoh Pentingsari pada kelestarian lingkungan merupakan salah satu bukti kedekatan warga Pentingsari terhadap alam khususnya pada lingkungan teritori (desa).

Berdasarkan penggalian karakter masyarakat di tiga lokasi dengan potensi yang berbeda dan latar belakang yang juga berbeda, maka hasil jejak ekologi dapat dilihat secara lebih bermakna. Gambaran budaya kehidupan masyarakat desa dalam relasinya dengan konsep kelestarian alam dapat disimpulkan seperti pada tabel 2 .

Tabel 2. Jejak ekologis Desa Wisata dan karakter masyarakat

\begin{tabular}{|c|c|c|c|c|c|c|c|}
\hline \multirow{3}{*}{ Desa wisata } & \multicolumn{6}{|c|}{ Perubahan jejak ekologis } & \multirow{3}{*}{$\begin{array}{l}\text { Karakter masyarakat } \\
\text { terkait dengan } \\
\text { kelestarian alam }\end{array}$} \\
\hline & \multicolumn{3}{|c|}{ Dari sisi warga desa } & \multicolumn{3}{|c|}{ Dari sisi wisatawan } & \\
\hline & Sebelum & Sesudah & Naik & Sebelum & Sesudah & Turun & \\
\hline $\begin{array}{l}\text { Desa } \\
\text { Pentingsari }\end{array}$ & 3.27 & 7.8 & $138.5 \%$ & 11.055 & 5.325 & $51.8 \%$ & $\begin{array}{l}\text { Memiliki sejarah } \\
\text { kedekatan dengan alam }\end{array}$ \\
\hline $\begin{array}{l}\text { Desa } \\
\text { Kalibiru }\end{array}$ & 7.3 & 9.1 & $24.7 \%$ & 10.83 & 6.69 & $38.2 \%$ & $\begin{array}{l}\text { Merintis kedekatan } \\
\text { dengan alam }\end{array}$ \\
\hline Desa Lopati & 9.75 & 11.55 & $18.5 \%$ & 11.88 & 6.15 & $48.2 \%$ & $\begin{array}{l}\text { Terpisah dari alam } \\
\text { (kesadaran belum } \\
\text { terbentuk) }\end{array}$ \\
\hline
\end{tabular}

Lain halnya dengan Desa Kalibiru yang merupakan warga yang hidup sederhana dari bertani dan sebagai penjual kayu bakar dari hutan sekitar. Desa Kalibiru pernah merasakan kekeringan yang berkepanjangan pada tahun 1997-2000 akibat hutan yang mulai gundul (Vincentia Reni Vitasurya 2016). Dan setelah kejadian ini masyarakat kelompok tani mulai melakukan reboisasi untuk menjaga kelestarian sumber air. Hutan rakyat yang dijaga saat ini menjadi pusat wisata alam dengan potensi pemandangan alam yang indah, namun kesadaran ini masih terbatas pada sekumpulan warga sudah peduli. Sebagian lain masih dalam tahap penyesuaian untuk lebih menyatu dengan alam.

Desa Lopati adalah desa yang sangat terbatas luas lahan pertanian. Sebagian masyarakat bermatapencaharian sebagai berdagang di pasar, pengusaha makanan tradisional, pengrajin bambu, dan buruh tani. Kehidupan yang demikian keras menjadikan warga Lopati menjadi pekerja keras dan tidak memiliki cukup waktu untuk memperhatikan kelestarian alam. Sejak tahun 2007 desa Lopati telah diresmikan menjadi desa wisata dan telah memiliki 34 homestay dan 32 diantaranya juga memiliki aneka usaha. Profil warga masyarakat Lopati yang demikian menyebabkan keterikatan dengan alam rendah. Penanganan limbah sisa industri belum dikelola dengan baik. Oleh karena itu karakter masyarakat Lopati meruapakan karakter pengusaha yang belum memiliki kesadaran menjaga kelestarian alam.

\section{Kajian antropologi untuk memperkaya analisis hasil jejak ekologis}

Seluruh indikator yang digunakan dalam perhitungan jejak ekologi sebenarnya berbasis pada tingkah laku yang juga terkait dengan gaya hidup manusia, namun model yang digunakan adalah model perhitungan individual. Pada kasus di perdesaan di Indonesia khususnya pada tiga kasus penelitian, gaya hidup manusia masih didominasi oleh gaya hidup kolektif. Warga desa sebagai makhluk sosial masih sangat kental di perdesaan, sehingga tingkah laku komunitas mempengaruhi kinerja pelestarian di perdesaan. Mengingat instrumen jejak ekologi merupakan alat ukur individual, maka gerakan kolektif kelestarian lingkungan yang ada di dalam masyarakat harus dipahami sebagai suatu gerakan sadar keberlanjutan lingkungan. Selain itu program pengelolaan wisata di perdesaan juga harus disusun agar menjadi gerakan kecintaan terhadap lingkungan dengan membangun kesadaran wisatawan untuk ikut serta menjaga keberlanjutan lingkungan. 
Tabel 3. Kajian antropologis tiap aspek jejak ekologis

\begin{tabular}{|c|c|c|c|}
\hline No & Indikator & Warga Desa & Wisatawan \\
\hline 1 & Aspek Transportasi & $\begin{array}{l}\text { Adakah aspek kesepakatan kolektif pengaturan } \\
\text { mobilitas penduduk terutama untuk melayani } \\
\text { tamu wisata }\end{array}$ & $\begin{array}{l}\text { Adakah kesadaran wisatawan saat } \\
\text { berkendaraan secara lebih hemat ke desa } \\
\text { wisata? }\end{array}$ \\
\hline 2 & $\begin{array}{l}\text { Aspek Penggunaan } \\
\text { Air }\end{array}$ & $\begin{array}{l}\text { Adakah pemahaman warga untuk menghemat } \\
\text { penggunaan air? Apakah pernah didiskusikan } \\
\text { pada rapat desa? }\end{array}$ & $\begin{array}{l}\text { Adakah kesadaran wisatawan saat } \\
\text { merasakan keterbatasan air di desa? }\end{array}$ \\
\hline 3 & $\begin{array}{l}\text { Aspek Penggunaan } \\
\text { Pakaian }\end{array}$ & $\begin{array}{l}\text { Adakah kesadaran untuk berpakaian sederhana } \\
\text { dan secukupnya? Dan bukan melakukan karena } \\
\text { keterbatasan? }\end{array}$ & $\begin{array}{l}\text { Adakah penjelasan penelola wisata tentang } \\
\text { berpakaian secukupnya saat berada di desa } \\
\text { wisata? Dan adakah kesadaran untuk } \\
\text { melakukan hal ini? }\end{array}$ \\
\hline 4 & Aspek rekreasi & $\begin{array}{l}\text { Adakah kesadaran warga desa dalam } \\
\text { menghabiskan waktu libur juga menerapkan } \\
\text { prinsip kelestarian lingkungan? }\end{array}$ & $\begin{array}{l}\text { Adakah penjelasan untuk membangun } \\
\text { kesadaran melakukan rekreasi secara } \\
\text { maksimal tanpa memaksimalkan sumber } \\
\text { daya? }\end{array}$ \\
\hline 5 & Aspek Makanan & $\begin{array}{l}\text { Adakah kesadaran warga desa bahwa makanan } \\
\text { lokal yang disajikan membawa pengaruh } \\
\text { positih bagi lingkungan? }\end{array}$ & $\begin{array}{l}\text { Adakah penjelasan dan penghargaan } \\
\text { kepada wisatawan saat mereka dapat } \\
\text { menikmati dengan rasa syukur makanan } \\
\text { lokal yang berdampak pada kesehatan } \\
\text { lingkungan? }\end{array}$ \\
\hline 6 & Aspek Sampah & $\begin{array}{l}\text { Adakah kesadaran warga desa saat mengelola } \\
\text { sampah wisata bahwa mereka telah } \\
\text { menyelamatkan lingkungan tempat tinggal } \\
\text { mereka dari kerusakan lingkungan? }\end{array}$ & $\begin{array}{l}\text { Adakah pembatasan dengan penjelasan } \\
\text { secukupnya mengenai sampah yang } \\
\text { dihasilkan wisatawan? }\end{array}$ \\
\hline 7 & $\begin{array}{l}\text { Aspek Tempat } \\
\text { Tinggal }\end{array}$ & $\begin{array}{l}\text { Adakah kesadaran bahwa homestay mereka } \\
\text { memberikan manfaat efisiensi ruang? }\end{array}$ & $\begin{array}{l}\text { Adakah kesadaran bahwa wisatawan telah } \\
\text { membantu kelestarian lingkungan dengan } \\
\text { berekreasi di desa wisata? }\end{array}$ \\
\hline
\end{tabular}

Fenomena rendahnya jejak ekologis saat menghabiskan waktu di desa wisata harus dimaknai sebagai satu kesadaran baik bagi warga desa maupun wisatawan, bahwa nilai rendah yang dihasilkan dari jejak ekologis mereka bukanlah kebetulan namun secara terstruktur menjadi gerakan untuk berubah. Jika pada masa lalu masyarakat secara sadar berperilaku secara sehat terhadap lingkungan alam di sekitar tempat tinggal, maka saat inipun secara sadar mereka mengalami secara bersama-sama sebagai gaya hidup untuk lebih dekat ke alam. Oleh karena itu setiap aspek yang diukur dari instrument jejak ekologis harus dipertanyakan dengan langkah kesadaran untuk mencapai lingkungan yang lebih baik. (Lihat tabel 3) Jika jawaban positif yang dihasilkan dari setiap pertanyaan, maka berarti angka jejak ekologi merupakan gerakan yang akan membawa perubahan positif terhadap lingkungan.

Dibandingkan dengan wisatawan yang berasal dari kota justru sebaliknya, mereka memiliki gaya hidup individual yang berakibat mempengaruhi komunitas dalam kelompok terlebih saat mereka berkegiatan bersama seperti berekreasi dalam kelompok. Oleh karena itu kajian antropologis merupakan bagian yang perlu dianalisis secara khusus agar memperkaya perhitungan jejak ekologi lebih bermakna sebagai alat evaluasi transformasi desa menjadi desa wisata sekaligus evaluasi berubahnya gaya berekreasi masyarakat perkotaan dari rekreasi masal menjadi rekreasi minat khusus ke desa wisata. (Lihat pada tabel 3)

Dari tabel 3 disimpulkan bahwa hasil jejak ekologi yang meingkat setelah desa menjadi desa wisata, sebenarnya tidak sepenuhnya demikian jika warga ataupun melalui pengelola desa wisata mengurangi dampak aktifitas tambahan desa wisata. Salah satu contoh adalah yang terjadi di desa Pentingsari saat menghadapi bertambahnya sampah anorganik dari wisatawan yang tinggal di desa wisata, pengelola berinisiatif untuk mengumpulkan sampah plastik botol minuman untuk kemudian setiap waktu tertentu akan dijual pada pengepul botol plastik. Aktifitas ini tidak terakomodasi dalam sistem perhitungan jejak ekologi karena pada alat bantu perhitungan hanya akan dihitung sebagai penghasil sampah yang besar dan berdampak nilai besar untuk aspek sampah. Pada kenyataannya upaya mengurangi sampah sebenarnya telah dilakukan dengan memilah sampah anorganik dan organik dan menjual sampah anorganik menjadi lebih berdaya guna.

Kasus seperti ini perlu menjadi catatan yang memiliki dampak sangat baik bagi pengelola desa wisata lain agar menjadi kesadaran bagi pengelola desa wisata dan selanjutnya ditularkan kepada 
seluruh warga desa. Keberhasilan desa Pentingsari dalam pengelolaan sampah anorganik di picu oleh pemimpin lokal yang secara langsung menangani pengelolaan sampah ini yang kemudian secara cepat ditiru oleh pengelola lain. Pada kasus ini juga terlihat gerakan kolektif masyarakat desa Wisata Pentingsari yang berawal dari kekuatan pemimpin lokal.

Berbeda dengan kasus desa Kalibiru yang telah memiliki kearifan lokal dalam pengelolaan hutan untuk mempertahankan sumber air tanah justru terjadi jauh sebelum desa Wisata berdiri yaitu sejak tahun 1995. Gerakan kolektif masyarakat Kalibiru dipicu oleh kekeringan di wilayah mereka pada masa lalu. Kekeringan yang melanda Desa Kalibiru mendorong gerakan kolektif masyarakat yang diprakarsai oleh sekelompok pemuda desa yang tergabung dalam gerakan pramuka dan kelompok tani yang diprakarsai oleh tokoh masyarakat desa saat ini. Tokoh inilah yang kemudian selain perannya dalam kelompok tani yang mejadikan kawasan hutan kemasyarakatan (HKM) juga ikut berperan dalam kelompok pengelola desa wisata, sehingga kehadiran desa wisata justru dikembangkan menjadi pemicu agar pengelola desa wisata adalah juga merupakan pengelola penjaga hutan (V. R. Vitasurya et al. 2015).

Keberlanjutan lingkungan tidak hanya tergantung dari aspek perhitungan fisik yang terkait dengan perilaku sesaat, namun lebih lanjut lagi pertimbangan lingkungan menjadi unsur penting untuk ditanamkan sejak dini. Lebih penting lagi, penelitian ini membantu pembuat kebijakan dan anggota masyarakat untuk membuat pembangunan yang sehat secara ekonomi, adil secara sosial dan ekologis (Moffatt 2000). Perhitungan jejak ekologis dengan mempertimbangkan pendekatan antropologi harus menjadi model yang dikembangkan untuk mendukung keberlanjutan desa wisata.

\section{Kesimpulan}

Jejak ekologi menghasilkan angka dampak perubahan gaya hidup dari desa biasa menjadi desa wisata, baik dari sisi warga desa, maupun dari sisi wisatawan. Membesarnya jejak ekologi bagi warga desa patut diwaspadai untuk lebih berupaya menjaga kelestarian lingkungan, akan tetapi perlu juga disadari bahwa bertambahnya jejak ekologi sangat dimungkinkan diakibatkan oleh perubahan internal masyarakat desa melalui gaya hidup warga desa sendiri. Demikian pula sebaliknya menurunnya jejak ekologi jangan sampai menjadikan legitimasi untuk melanjutkan gaya hidup saat ini, karena angka jejak ekologi hanya bermakna jika juga diikuti oleh pemahaman akan gaya hidup sehat yang memberi dampak positif bagi keberlanjutan bumi dan bukan semata-mata puas dengan penurunan jejak ekologi. Oleh karena itu pemahaman secara lebih mendalam terkait kehidupan manusia dalam konteks kemasyarakatan perlu dikembangkan untuk memahami fakta empirik di lapangan yang sangat sarat dengan kehidupan sosial yang sulit diukur dengan sebuah model pengukuran sederhana.

Model perhitungan sederhana jejak ekologi dipilih untuk secara mudah dipahami oleh pengguna utama yaitu masyarakat perdesaan. Dan sebagai catatan model jejak ekologi sederhana ini hanya mengukur dampak aktifitas secara individual. Akan tetapi kesadaran hidup bermasyarakat dengan berbagai gerakan kolektif perlu dilengkapi sebagai bagian catatan penting yang tidak terpisahkan dari hasil jejak ekologi. Pemahaman akan makna dibalik angka jejak ekologi harus dipahami sebagai suatu gerakan yang secara antropologis membawa perubahan gaya hidup yang lebih baik. Untuk kemudahan membaca makna angka jejak ekologi, maka dikembangkan pertanyaan untuk setiap aspek, yang menunjukkan nilai sesungguhnya dari aktivitas yang telah dilakukan dengan pengembangan desa Wisata. Keterbatasan alat ukur jejak ekologi sederhana dilengkapi dengan sejumlah pertanyaan yang jika didapat jawanan positif maka angka yang dihasilkan memang merupakan angka mendekati riil.

\section{Referensi}

Baal, J. van. 1988. Sejarah Pertumbuhan Teori dan Antropologi Budaya (Hingga Dekade 1970). Diedit oleh J. Drs. Piry. Terjemahan. Jakarta: PT. Gramedia.

Bagliani, M., E. Da Villa, M. Gattolin, V. Niccolucci, T. Patterson, dan E. Tiezzi. 2004. "The ecological footprint analysis for the Province of Venice and the relevance of tourism." In Advances in Architecture Series.

Fandeli, Chafid. 2002. "Perencanaan Kepariwisataan Alam.” Yogyakarta. 
Footprint, Ecological. 2016. "Ecological Footprint Quiz."

Frangialli, F. 1999. "Global Code of Ethics for Tourism." Message from the SecretaryGeneral of WTO: ....

Hwang, Doohyun, William P. Stewart, dan Dong wan Ko. 2012. "Community behavior and sustainable rural tourism development." Journal of Travel Research. https://doi.org/10.1177/0047287511410350.

Mikkelsen, Britha. 1995. "Participation - Concept and Methods." Methods for Development Work and Research: A Guide to Practitioners.

Moffatt, I. 2000. "Ecological footprints and sustainable development." Ecological Economics. https://doi.org/10.1016/S09218009(99)00154-8.

Patterson, Trista M., Valentina Niccolucci, dan Simone Bastianoni. 2007. "Beyond 'more is better': Ecological footprint accounting for tourism and consumption in Val di Merse, Italy." Ecological Economics. https://doi.org/10.1016/j.ecolecon.2006.09.01 6.

Purbadi, Yohanes Djarot, dan Reginaldo Christophori Lake. 2019. "Konsep KampungWisata Sejahtera, Kreatif, Cerdas dan Lestari Berkelanjutan.” EMARA: Indonesian Journal of Architecture. https://doi.org/10.29080/eija.v5i1.641.

Reid, Margaret. 2006. "Barriers to sustainable development: Jordan's sustainable tourism strategy." Journal of Asian and African Studies. https://doi.org/10.1177/0021909606067408.

Reni Vitasurya, V, Anna Pudianti, Anna Purwaningsih, dan Herawati. 2014. "Kearifan Lokal dalam Pengelolaan Lingkungan Desa Wisata Kalibiru, di D.I Yogyakarta." Jurnal.

Sthel, Marcelo S., José G. R. Tostes, dan Juliana R. Tavares. 2013. "Current energy crisis and its economic and environmental consequences: Intense human cooperation." Natural

Science. https://doi.org/10.4236/ns.2013.52a036.

Südaş, Hatice Doğan, dan Eda Yaşa Özeltürkay. 2015. "Analyzing the Thoughts of Ecological Footprints of University Students: A Preliminary Research on Turkish Students." Procedia - Social and Behavioral Sciences. https://doi.org/10.1016/j.sbspro.2015.01.118.

Vincentia Reni, VITASURYA, dan PUDIANTI Anna. 2016. "SUSTAINABLE WASTE MANAGEMENT OF TRADITIONAL CRAFT INDUSTRY IN LOPATI TOURISM VILLAGE, YOGYAKARTA." DIMENSI (Journal of Architecture and Built Environment).

https://doi.org/10.9744/dimensi.43.2.123130.

Vitasurya, V.R, A. Pudianti, A. Purwaningsih, dan A. Herawati. 2015. "Kearifan lokal daam Pengelolaan Lingkungan desa wisata Kalibiru, di D.I Yogyakarta, dipresentasikan pada." In Prosiding Seminar Nasional SCAN\#6 Universitas Atma Jaya Yogyakarta.

Vitasurya, Vincentia Reni. 2016. "Local Wisdom for Sustainable Development of Rural Tourism, Case on Kalibiru and Lopati Village, Province of Daerah Istimewa Yogyakarta." Procedia - Social and Behavioral Sciences. https://doi.org/10.1016/j.sbspro.2015.12.014.

Wackernagel, Mathis, dan Chad Monfreda. 2004. "Ecological Footprints and Energy." In Encyclopedia of Energy. https://doi.org/10.1016/b0-12-176480$\mathrm{x} / 00120-0$

Wackernagel, Mathis, William Rees, Mathis Wacker nagel, dan B Meredith Burke. 1997. "M. Wackernagel, W. Rees Our Ecological Footprint: Reducing Human Impact on the Earth New Society Publishers, C." Population and Environment.

Wang, Shuxin, Yiyuan Hu, Hong He, dan Genxu Wang. 2017. "Progress and prospects for tourism footprint research." Sustainability (Switzerland). https://doi.org/10.3390/su9101847. 